\title{
Article \\ Application of Enterococcus malodoratus SJC25 for the Manufacture of Whey-Based Beverage Naturally Enriched with GABA
}

\author{
Daniela S. Cunha, Márcia C. Coelho, Susana C. Ribeiro (1) and Celia C. G. Silva *(1)
}

Citation: Cunha, D.S.; Coelho, M.C.; Ribeiro, S.C.; Silva, C.C.G.

Application of Enterococcus

malodoratus SJC25 for the

Manufacture of Whey-Based

Beverage Naturally Enriched with

GABA. Foods 2022, 11, 447.

https://doi.org/10.3390/foods11030447

Academic Editor: Fani Mantzouridou

Received: 22 December 2021

Accepted: 29 January 2022

Published: 2 February 2022

Publisher's Note: MDPI stays neutral with regard to jurisdictional claims in published maps and institutional affiliations.

Copyright: (C) 2022 by the authors. Licensee MDPI, Basel, Switzerland. This article is an open access article distributed under the terms and conditions of the Creative Commons Attribution (CC BY) license (https:// creativecommons.org/licenses/by/ $4.0 /)$
Institute of Agricultural and Environmental Research and Technology (IITAA), University of the Azores, 9700-Angra do Heroísmo, Portugal; daniela.sv.cunha@gmail.com (D.S.C.); marciacoelho8282@gmail.com (M.C.C.); susana.ic.ribeiro@uac.pt (S.C.R.)

* Correspondence: celia.cg.silva@uac.pt; Tel.: +351-295402200

\begin{abstract}
Gamma-aminobutyric acid (GABA) is used as a dietary supplement because of its healthpromoting properties. However, concern over the use of synthetic products has increased the demand for foods that are naturally fortified with GABA. In addition, excess whey is a major concern for the dairy industry due to the high cost of treating it. Here, we report the use of a novel Enterococcus malodoratus strain isolated from cheese to produce sweet whey beverages naturally enriched with GABA. After the screening of cheese isolates, E. malodoratus strains were identified as high GABA producers. One beverage was prepared from pasteurized sweet whey enriched in glutamic acid and E. malodoratus SJC25. The fermented beverages were supplemented with a fruit preparation and subjected to chemical, microbiological and sensory analysis. The bacterial counts and GABA content were maintained until storage at $4{ }^{\circ} \mathrm{C}$ for 14 days. High conversion rates of glutamic acid to GABA (50-71\%) were obtained in the beverages. The GABA content in whey-based beverages reached $250-300 \mathrm{mg} / 100 \mathrm{~mL}$, which is equivalent to the content of commercially available GABA supplements. The beverages received a positive rating $(4 / 5)$ by the taste panel. To our knowledge, this is the first report on E. malodoratus as a potential GABA producer.
\end{abstract}

Keywords: GABA; whey; milk; LAB; dairy; probiotics; glutamic acid; cheese; fermentation

\section{Introduction}

Motivated by consumer health consciousness, the food industry has prompted researchers to develop a greater variety of healthy products with the addition of probiotics and bioactive compounds [1]. Commercially available probiotics mainly include strains of Lactobacillus spp. and Bifidobacterium spp. used in fermented dairy products [2,3]. In addition, other bacterial species such as Streptococcus spp., Bacillus spp. and Enterococcus spp. are widely used as probiotics in foods and dietary supplements due to their high survival rate in the gut and associated high biological activities [2,4-7].

Currently, the most internationally accepted definition of a probiotic comes from the Food and Agriculture Organization of the United Nations/World Health Organization, which defines probiotics as "live microorganisms administered in sufficient quantity to provide a health benefit to the host" [8]. From a technological point of view, probiotic microorganisms must allow large-scale production, withstand processing, have a stable acidity, and have an appropriate taste and pleasant texture after fermentation. They must also maintain a high number of viable cells during storage [9].

Several studies have reported the ability of probiotics to alleviate psychological stress in humans and to exert anxiolytic effects in rats, contributing to a growing body of evidence that the gut microbiota can influence the nervous system [10-12]. Gamma-aminobutyric acid (GABA) is the main inhibitory neurotransmitter in the central nervous system and has been associated with beneficial health effects such as relaxing and calming effects, with 
a particular emphasis on the antihypertensive effect demonstrated in animal and human studies [13]. Studies have also demonstrated the ability of various lactic acid bacteria (LAB) to produce GABA, belonging to Lactococcus, Lactobacillus and Streptococcus [7,14]. The production of this neurotransmitter by using LAB in fermented foods is a preferred alternative to satisfy the demand for naturally GABA-enriched products [15]. A still unclear issue is the amount and frequency of consumption of probiotics necessary to ensure the functional benefits. Although, some authors recommend a minimum daily intake of $100 \mathrm{~g}$ of fermented dairy products containing $10^{7} \mathrm{CFU} / \mathrm{mL}$ [16].

Whey is the watery part of milk which separates from the curds in the manufacture of cheese. A distinction is made between sweet whey, which is obtained by the addition of rennet $(\mathrm{pH}=6-7)$, and acid whey, when coagulation occurs through the action of acid $(\mathrm{pH}<5)$ [17]. This by-product contains about $50 \%$ of the nutrients/dry matter of milk [18], including lactose $(70-80 \% \mathrm{DM})$, proteins (9\% DM), minerals (8-20\% DM) and other minor components $[17,19]$. The content of lactose and other nutrients makes whey a potential raw material for the development of probiotic microorganisms that enable the production of fermented beverages $[18,20]$. As a by-product of cheese production, whey can pollute the environment [21]. The excess of this by-product is one of the major problems for the dairy industry, especially for small and medium enterprises, because the cost of its treatment is high [22]. Dairy beverages fermented from whey and with probiotic cultures added represent an excellent innovative alternative, as they have functional properties and allow the use of whey, minimizing the negative impact on the environment, without requiring large investments or significant changes in the production routine [21]. Studies reporting the development of fermented dairy beverages from whey show high acceptance from a sensory point of view [23-26].

In previous studies, lactic acid bacteria were isolated from an artisanal cheese made from raw cow's milk [27]. The aim of the present work was to screen these isolates for converting glutamic acid to GABA and evaluate the use of a GABA producer-E. malodoratus SJC25 in the preparation of a drink made from cow's whey, to which a fruit concentrate was added to improve its sensory properties. To this end, we studied the GABA content and the physicochemical and sensory properties of the fermented whey-based beverages. To our knowledge, this is the first report of the use of E. malodoratus as a GABA producer in a flavored beverage made from sweet whey.

\section{Materials and Methods}

\subsection{Screening of GABA-Producing $L A B$}

A total of 27 strains of lactic acid bacteria (LAB) previously isolated from traditional Azorean cheeses (made from non-pasteurized cow's milk), were screened for their GABAproducing ability.

The 16S rDNA sequences of isolates have been deposited in the GenBank under accession numbers MT742854-MT742858, MT742859, MT742860, MT742864, MT742869, MT742871, MT742872, MT742878, MT742883, MT742900-MT742907, MT742917-MT742923.

Before being used, the strains were propagated in de Man Rogosa Sharpe (MRS) broth (AES, France) and incubated at $30{ }^{\circ} \mathrm{C}$ (non-shaking aerobic incubation), for $48 \mathrm{~h}$. In order to select a LAB with high GABA-producing ability, the optical density (OD) of the inoculum was adjusted to 6.0-6.5 on the McFarland scale. Aliquots of $50 \mu \mathrm{L}$ of each sample were inoculated into $5 \mathrm{~mL}$ of MRS broth, supplemented with 3\% glutamic acid (Sigma, Darmstadt, Germany), followed by incubation at $30{ }^{\circ} \mathrm{C}$ for $72 \mathrm{~h}$. After incubation, media were centrifuged at 14,000 $\times g$ for $10 \mathrm{~min}$ (model 5804R, Eppendorf, Darmstadt, Germany) and supernatants were stored at $-17^{\circ} \mathrm{C}$ until analysis of GABA and glutamic acid (GLU).

\subsection{Quantification of GABA and GLU}

GABA and GLU contents were determined by HPLC (VWR Hitachi, model Elite Lachrom, Japan) equipped with an automated injector, and a RP-18 column (Purospher ${ }^{\circledR}$ STAR, $5 \mu \mathrm{m}$ particle size), according to the method described by Li et al. [28], with some 
modifications. Briefly, samples $(100 \mu \mathrm{L})$ of culture MRS broth with 3\% GLU (supernatants) or fermented beverages were mixed with $900 \mu \mathrm{L}$ of $20 \%$ trichloroacetic acid (TCA, Sigma, Darmstadt, Germany). The mixture was vortexed and centrifuged for $10 \mathrm{~min}$ at $4000 \times g$. After centrifugation, the supernatant was filtered with $0.45 \mu \mathrm{m}$ filters (Whatman, Darmstadt, Germany) and used for HPLC analysis. Standards and samples were previously derivatized with $o$-phtaldehyde (OPA). The derivatization reagent (OPA) was prepared with $10 \mathrm{mg}$ of $o$-phtaldehyde (Sigma), $10 \mu \mathrm{L}$ of 2-mercaptoethanol (99\% extra pure, Acros organics, Geel, Belgium) and $2.5 \mathrm{~mL}$ of acetonitrile (Sigma), in a tube protected from light. For the derivatization reaction, $100 \mu \mathrm{L}$ of sample/standard was mixed with $500 \mu \mathrm{L}$ of borate buffer $(0.4 \mathrm{M}, \mathrm{pH} 10.4)$ and $100 \mu \mathrm{L}$ of OPA. The mixture was vortexed for $30 \mathrm{~s}$ and reacted at room temperature for $5 \mathrm{~min}$ and was immediately injected $(20 \mu \mathrm{L})$ into the HPLC apparatus. The separation of OPA-derivatives was performed with a mobile phase consisting of ammonium acetate buffer $(0.02 \mathrm{M}, \mathrm{pH} 7.3)$ as solvent $\mathrm{A}$, and acetonitrile as solvent $\mathrm{B}$. The gradient elution program was set at $80 \%$ solvent $A$ and $20 \%$ solvent $B$ for 8 min, ramped at $100 \%$ of $B$ for $8 \mathrm{~min}$, then at $20 \%$ of $B$ until the end of the run $(25 \mathrm{~min})$, with a flow rate of $0.6 \mathrm{~mL} / \mathrm{min}$. Detection was performed with a Diode Array Detector (DAD), at a wavelength of $334 \mathrm{~nm}$. Calibration curves for GABA and glutamic acid (GLU) were produced using standard standards of GABA $(100,200,300,400,500$ and $600 \mathrm{mg} / \mathrm{L})$ and GLU (1, 2.5, and $5 \mathrm{~g} / \mathrm{L})$.

\subsection{Beverage Production}

The main raw material used in the formulation of the drink was cow's sweet whey with an average $\mathrm{pH}$ of 6.44 , resulting from the production of cured cheese, and was supplied by a cheese producer (Quinta dos Açores, Terceira, Portugal).

The whey was subjected to pasteurization at $90{ }^{\circ} \mathrm{C}$ for $5 \mathrm{~min}$. After completing the pasteurization, the whey was cooled in an ice bath until reaching a temperature of $30-32{ }^{\circ} \mathrm{C}$. The beverages were produced with the LAB culture with the greatest potential for producing GABA. The inoculum (5\% E. malodoratus SJC25 culture, 6.0-6.5 McFarland scale) was centrifuged at $4000 \times g$ for $10 \mathrm{~min}$, at $10^{\circ} \mathrm{C}$ (Eppendorf centrifuge, Model 5804R, Darmstadt, Germany). In order to eliminate all traces of MRS broth, the pellet was washed twice with $20 \mathrm{~mL}$ of sterilized water.

Fermentation was performed using sweet whey supplemented with GLU $(0.5 \%)$ and $5 \%(v / v)$ of GABA-producer (E. malodoratus SJC25 culture). After addition of inoculum (5\%), fermentation started in an incubator hood (TH 30, Edmund Bühler GmbH, Bodelshausen, Germany) combined with a universal shaker (80 rpm, Edmund Bühler $\mathrm{GmbH}$ ), at $30{ }^{\circ} \mathrm{C}$ for $48 \mathrm{~h}$. The fermented whey was then separated into two sterilized flasks, and $9 \%$ of fruit preparation was added to test 2 different formulations: (1) pineapple beverage: whey + GLU $(0.5 \%)+5 \%(v / v)$ E. malodoratus SJC25 + 9\% pineapple preparation (water, 30\% pineapple puree, sucrose, modified starch, flavors, preservative: potassium sorbate, acidity regulators: citric acid and trisodium citrate and coloring: lutein); (2) passion fruit beverage: whey + GLU $(0.5 \%)+5 \%(v / v)$ E. malodoratus SJC25 + 9\% passion fruit preparation (water, $30 \%$ passion fruit puree, sucrose, modified starch, acidity regulators: trisodium citrate and citric acid, flavors, preservative: potassium sorbate and coloring: beta carotene). A control formulation was used with whey + GLU (0.5\%). Beverages were kept in the refrigerator $\left(4^{\circ} \mathrm{C}\right)$ until being analyzed after 0,7 and 14 days. Experiments were performed in triplicate.

The process flowchart is presented in Figure 1 and the images of finished beverages in Figure 2. 


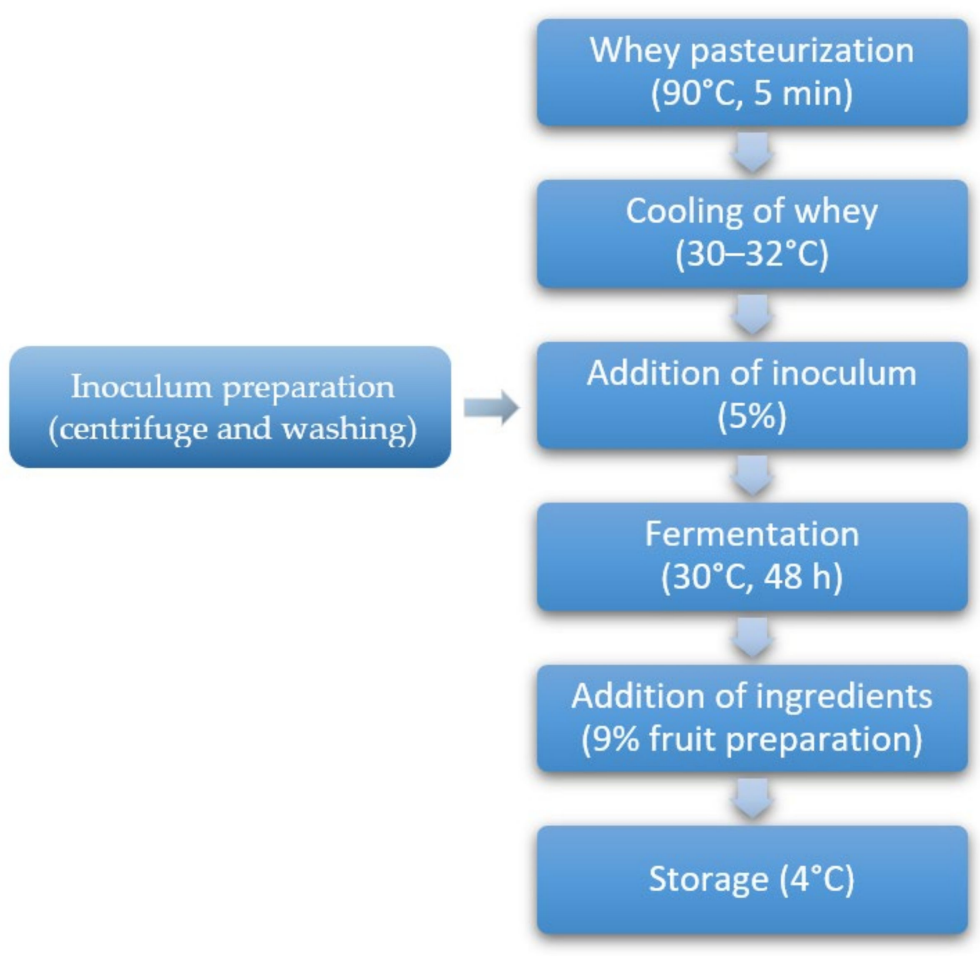

Figure 1. Protocol for the manufacture of the fermented whey beverage with E. malodoratus SJC25 culture.

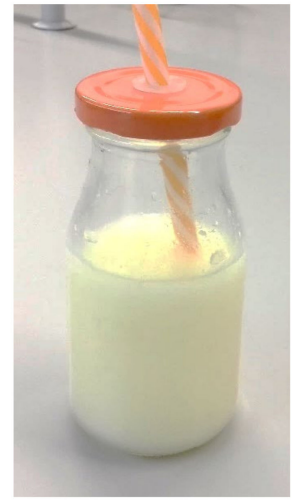

(a)

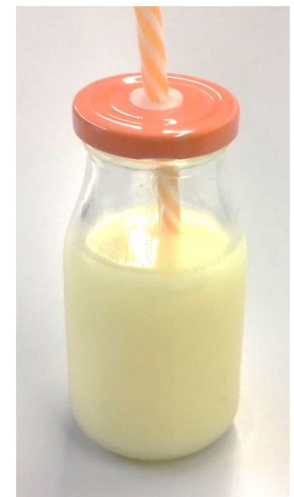

(b)

Figure 2. Presentation of the finished product-fermented whey beverage with E. malodoratus SJC25. (a) Pineapple flavored beverage; (b) passion fruit flavored beverage.

\subsection{Microbiology Analysis}

At the end of fermentation, all samples of beverages were serial diluted in peptone water (AES, Rennes, France), plated on MRS (Biokar, Allonne, France), and incubated at $30{ }^{\circ} \mathrm{C}$ for $48 \mathrm{~h}$.

Bacterial counts were performed after whey pasteurization, before starting fermentation, at $24 \mathrm{~h}$ of fermentation, and in the fermented beverage at 0,7 and 14 days of storage. Bacterial counts were performed in duplicate.

\subsection{Chemical Analysis}

To evaluate moisture content in the final product, the AOAC method was used [29]. Briefly, $5 \mathrm{~g}$ of each sample was dried in the oven at $103^{\circ} \mathrm{C}$ for $24 \mathrm{~h}$. Samples were evaluated in quadruplicate. 
Titratable acidity was determined by direct titration of $10 \mathrm{~mL}$ of each sample, according to the AOAC method [29]. pH was measured directly with a pH meter (WTW Inolab pH Level 1, Weilheim, Germany).

Total sugars were determined according to the method of Dubois et al. [30]. Samples were diluted 1:1000, added $(2 \mathrm{~mL})$ to $0.10 \mathrm{~mL}$ of phenolic solution and $5 \mathrm{~mL}$ of concentrated sulfuric acid. The tubes were vortexed and cooled for $20 \mathrm{~min}$. Absorbance was read on a UV/Vis spectrophotometer (U-2900, Hitachi, Tokyo, Japan) at $490 \mathrm{~nm}$. A calibration curve was constructed with the following glucose concentrations: $0,12.5,25,37.5$ and $50 \mu \mathrm{g} / \mathrm{mL}$. Analyses were performed in triplicate.

Fat content was determined by the Gerber method [29]. In a butyrometer, $10 \mathrm{~mL}$ of sulphuric acid was added to $11 \mathrm{~mL}$ of the beverage and $1 \mathrm{~mL}$ of amyl alcohol, followed by mixing. The butyrometers were centrifuged in the Gerber centrifuge for $5 \mathrm{~min}$ at $1200 \mathrm{rpm}$. Then, they were placed in a water bath at $65{ }^{\circ} \mathrm{C}$ for $5 \mathrm{~min}$, and the fat percentage was measured directly in the butyrometer.

Total protein content was calculated from the amount of nitrogen determined by the Micro Kjeldahl method [29]. Nitrogen was converted into protein via multiplication by a factor of 6.38. Briefly, $0.5 \mathrm{~g}$ of each sample was digested with sulphuric acid, followed by a distillation with $\mathrm{NaOH}$ in $2 \%$ boric acid $(w / v)$. Finally, titration of the obtained distillate was carried out by using $0.1 \mathrm{~N} \mathrm{HCl}$.

\subsection{Sensorial Analysis}

Sensory tests were performed to determine the degree of acceptance of the wheybased pineapple and passion fruit beverages. Acceptance tests were carried out on fresh beverages (1-2 days after fermentation) by a panel of 31 untrained adult tasters, usual consumers of dairy products, with a mean age of $37.0 \pm 13.2$ years (58\% women and $42 \%$ men). The attributes judged were flavor, aroma, texture and global appreciation. A hedonic scale was used from 1 to 5 points, where 5 represented "Very pleasant/I like it very much" and 1 "Very unpleasant/I do not like anything". Grades 1 and 2 represented indicators of non-acceptance of beverages. The evaluation regarding the degree of intensity of the attributes acidity and sweetness were evaluated using a scale from 1 to 5 points, where 5 represented "Very intense" and 1 "Slightly intense".

\subsection{Statistical Analysis}

The analyses were conducted in 3 replicates and presented as mean \pm standard error of the mean (SEM). Significant differences between GABA content, $\mathrm{pH}$ and bacterial counts throughout storage of beverages were evaluated by one-way analysis of variance (ANOVA) using IBM SPSS Statistics, version 25 (IBM Corporation, New York, NY, USA).

\section{Results}

\subsection{Screening of GABA-Producing $L A B$}

The results of GABA production in a culture medium enriched with GLU and the respective conversion rate are shown in Table 1 . The screening of 27 isolates for the production of GABA included Enterococcus faecalis, E. gilvus, E. malodoratus, E. devriesei, Lacticaseibacillus casei (former Lactobacillus casei), Lacticaseibacillus paracasei (former Lactobacillus paracasei) and Leuconostoc mesenteroides. 
Table 1. Screening of lactic acid bacteria (LAB) for production of $y$-aminobutyric acid (GABA) in MRS broth after $48 \mathrm{~h}$. Values of GABA concentration $(\mathrm{mg} / \mathrm{L})$ and percentage of conversion (calculated as the percentage of glutamic acid added to medium converted to GABA) are indicated.

\begin{tabular}{|c|c|c|c|c|}
\hline Species Identification & Isolate & Accession Number & GABA (mg/L) & Conversion $(\%)$ \\
\hline Enterococcus faecalis & SJC20 & MT742854 & 1787 & 6.0 \\
\hline Enterococcus gilvus & SJC21 & MT742855 & 0 & 0 \\
\hline Enterococcus gilvus & SJC22 & MT742856 & 1403 & 4.7 \\
\hline Enterococcus malodoratus & SJC24 & MT742858 & 11,021 & 36.7 \\
\hline Enterococcus malodoratus & SJC25 & MT742859 & 13,062 & 43.5 \\
\hline Enterococcus malodoratus & SJC26 & MT742860 & 12,823 & 42.7 \\
\hline Enterococcus faecalis & SJC30 & MT742864 & 208 & 0.7 \\
\hline Enterococcus devriesei & SJC35 & MT742869 & 678 & 2.3 \\
\hline Enterococcus faecalis & SJC37 & MT742871 & 0 & 0 \\
\hline Enterococcus faecalis & SJC38 & MT742872 & 16 & 0.1 \\
\hline Enterococcus faecalis & SJC44 & MT742878 & 0 & 0 \\
\hline Enterococcus faecalis & SJC49 & MT742883 & 0 & 0 \\
\hline Lacticaseibacillus casei & SJC66 & MT742900 & 2391 & 8.0 \\
\hline Enterococcus faecalis & SJC67 & MT742901 & 818 & 2.7 \\
\hline Leuconostoc mesenteroides & SJC68 & MT742902 & 318 & 1.1 \\
\hline Enterococcus faecalis & SJC69 & MT742903 & 2477 & 8.3 \\
\hline Enterococcus faecalis & SJC70 & MT742904 & 1278 & 4.3 \\
\hline Leuconostoc mesenteroides & SJC71 & MT742905 & 1269 & 4.2 \\
\hline Leuconostoc mesenteroides & SJC72 & MT742906 & 0 & 0 \\
\hline Enterococcus faecalis & SJC73 & MT742907 & 2667 & 8.9 \\
\hline Enterococcus faecalis & SJC83 & MT742917 & 2197 & 7.3 \\
\hline Lacticaseibacillus paracasei & SJC84 & MT742918 & 2125 & 7.1 \\
\hline Enterococcus faecalis & SJC85 & MT742919 & 2429 & 8.1 \\
\hline Enterococcus faecalis & SJC86 & MT742920 & 2988 & 10.0 \\
\hline Lacticaseibacillus casei & SJC87 & MT742921 & 2354 & 7.8 \\
\hline Lacticaseibacillus paracasei & SJC88 & MT742922 & 803 & 2.7 \\
\hline Lacticaseibacillus paracasei & SJC89 & MT742923 & 2647 & 8.8 \\
\hline
\end{tabular}

In the present study, GABA production ranged from 0 to $13 \mathrm{~g} / \mathrm{L}$, which corresponded to a conversion rate between 0 and $54.7 \%$. Of the $27 \mathrm{LAB}$ isolates studied, three clearly stood out for their high potential for GABA production. The isolates identified as E. malodoratus SJC24, SJC25 and SJC26 achieved a GABA concentration in the culture medium of 11.0, 13.1 and $12.8 \mathrm{~g} / \mathrm{L}$, respectively. Isolate SJC25 produced the highest amount of GABA, with a conversion rate of $43.5 \%$. Therefore, this isolate was selected as inoculum for further fermentation of milk beverages.

\subsection{Production of GABA in Fermented Beverages}

An example of a chromatogram of a passion fruit whey-based beverage with 14 days of storage at $4{ }^{\circ} \mathrm{C}$ is shown in Figure 3. The first peak corresponds to GLU with a retention time of $1.8 \mathrm{~min}$ and the second peak corresponds to GABA with a retention time of $3.1 \mathrm{~min}$.

In both the fermented pineapple and passion fruit beverages, the conversion rates obtained were very high (50-71\%).

In the fermented pineapple drink, the original GABA content $(2.699 \mathrm{~g} / \mathrm{L})$ was maintained for 14 days at $4{ }^{\circ} \mathrm{C}$. GABA content in both pineapple and passion fruit beverages was not significantly different $(p>0.05)$ between different days. In both beverages, residual amounts of GLU were detected in the final product due to the high conversion rates to GABA.

The GABA concentrations obtained in the passion fruit and pineapple beverages are shown in Table 2. The control was the whey without free GLU or GABA. In the whey fortified with $0.5 \% \mathrm{GLU}$, a concentration of $4.62 \mathrm{~g} / \mathrm{L}$ was obtained (recovery rate of $92.4 \%$ ). 


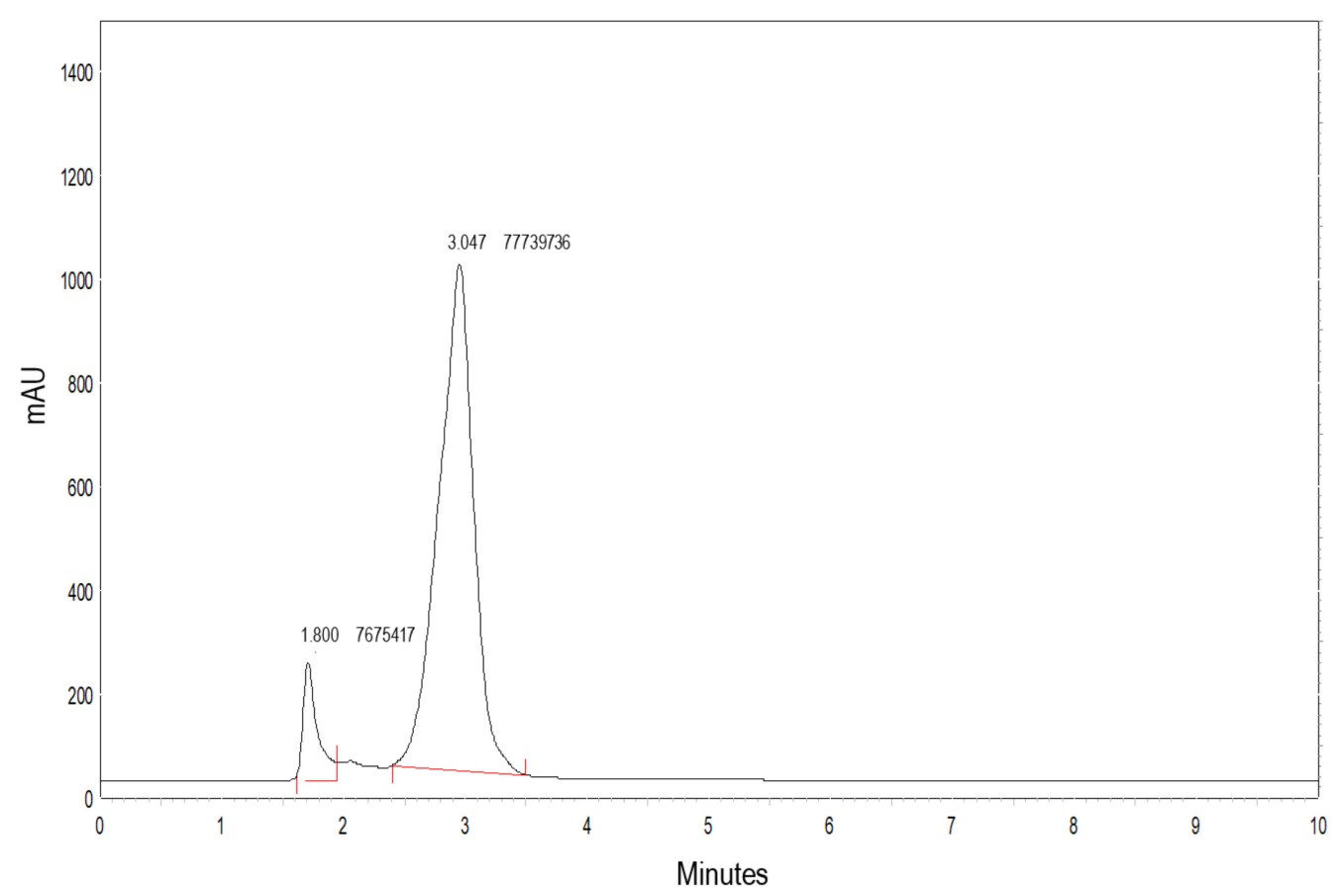

Figure 3. Example of a chromatogram obtained from passion fruit flavor of fermented whey beverage with E. malodoratus SJC25, after 14 days of storage at $4{ }^{\circ} \mathrm{C}$.

Table 2. GLU and GABA concentration in unfermented whey and fermented whey with E. malodoratus SJC25 (pineapple and passion fruit flavor beverages). Data are presented as mean \pm SEM.

\begin{tabular}{cccc}
\hline Sample & Time (Days) & GLU (g/L) & GABA (g/L) \\
\hline Whey & 0 & ND $^{*}$ & ND $^{*}$ \\
\hline Whey + GLU $(5 \mathrm{~g} / \mathrm{L})$ & 0 & $4.620 \pm 0.531$ & ND $^{*}$ \\
\hline Whey beverage & 0 & $0.433 \pm 0.058$ & $2.699 \pm 0.230$ \\
Pineapple flavor & 7 & $0.351 \pm 0.047$ & $2.319 \pm 0.198$ \\
& 14 & $0.231 \pm 0.031$ & $3.117 \pm 0.266$ \\
Whey beverage & 0 & $0.310 \pm 0.036$ & $3.272 \pm 0.198$ \\
Passion fruit flavor & 7 & $0.200 \pm 0.023$ & $3.178 \pm 0.192$ \\
& 14 & $0.303 \pm 0.035$ & $2.636 \pm 0.160$ \\
\hline
\end{tabular}

*ND: not detected (under detection limit).

\subsection{Physico-Chemical and Microbiological Analysis of Beverages}

The whey (sweet whey) used in the formulation of the beverages had an initial $\mathrm{pH}$ of 6.44, but before fermentation the $\mathrm{pH}$ was lowered to $4.35 \pm 0.02$ as a result of the addition of GLU. At the end of fermentation (after $48 \mathrm{~h}$ ), the $\mathrm{pH}$ of the whey was $4.27 \pm 0.01$ (data not shown). The pineapple and passion fruit preparations added to the fermented whey also had a low $\mathrm{pH}(3.8 \pm 0.2)$.

The results of $\mathrm{pH}$, titratable acidity and chemical analyses of the fermented beverages (pineapple and passion fruit) are summarized in Table 3. 
Table 3. Proximate composition of fermented whey beverages. Samples were analyzed after fermentation and are presented as the average of two samples \pm SEM.

\begin{tabular}{ccc}
\hline & Pineapple Beverage & Passion Fruit Beverage \\
\hline Titratable acidity $(\mathrm{g}$ LA $/ 100 \mathrm{~mL})$ & $0.63 \pm 0.07$ & $0.73 \pm 0.06$ \\
$\mathrm{pH}$ & $4.30 \pm 0.04$ & $4.28 \pm 0.03$ \\
Moisture $(\mathrm{g} / 100 \mathrm{~mL})$ & $89.8 \pm 0.04$ & $90.2 \pm 0.01$ \\
Total sugar $(\mathrm{g} / 100 \mathrm{~mL})$ & $8.7 \pm 1.1$ & $6.5 \pm 0.82$ \\
Total fat $(\mathrm{g} / 100 \mathrm{~mL})$ & $1.0 \pm 0.2$ & $1.0 \pm 0.2$ \\
Protein $(\mathrm{g} / 100 \mathrm{~mL})$ & $0.535 \pm 0.023$ & $0.513 \pm 0.022$ \\
\hline
\end{tabular}

Microbiological analyses were performed on the whey after pasteurization (control) and resulted in zero counts in MRS agar. After addition of the inoculum (E. malodoratus SJC25) to the whey and before the start of fermentation, the bacterial count was $6.10 \pm 0.07 \mathrm{Log} \mathrm{CFU} / \mathrm{mL}$. At the end of fermentation $(48 \mathrm{~h})$, the average count of LAB was $6.24 \pm 0.19 \mathrm{Log} \mathrm{CFU} / \mathrm{mL}$ (data not shown).

$\mathrm{LAB}$ counts in the beverages stored at $4{ }^{\circ} \mathrm{C}$ for 14 days are shown in Table 4 . During the 14-day storage period, the LAB count remained relatively constant at approximately $6 \mathrm{Log}$ CFU $/ \mathrm{mL}$. There were no statistically significant differences $(p>0.05)$ between different days in $\mathrm{pH}$ values and bacterial counts. In the pasteurized whey without the addition of the inoculum, LAB was not detected until the 14-day storage at $4{ }^{\circ} \mathrm{C}$.

Table 4. Total $\mathrm{LAB}$ counts ( $\log \mathrm{CFU} / \mathrm{mL}$ ) on pasteurized whey without addition of inoculum and whey beverages with addition of E. malodoratus SJC25, for 14 days of storage at $4{ }^{\circ} \mathrm{C}$. Values are the average of duplicates \pm SEM.

\begin{tabular}{cccccc}
\hline \multirow{2}{*}{ Time (Days) } & \multirow{2}{*}{$\begin{array}{c}\text { Whey * } \\
\text { Log UFC/mL }\end{array}$} & \multicolumn{2}{c}{ Pineapple Beverage } & \multicolumn{2}{c}{ Passion Fruit Beverage } \\
\cline { 3 - 6 } & ND & $\mathbf{p H}$ & Log CFU/mL & $\mathbf{p H}$ & Log CFU/mL \\
\hline 0 & ND & $4.30 \pm 0.04$ & $6.20 \pm 0.10$ & $4.28 \pm 0.03$ & $6.30 \pm 0.15$ \\
\hline 7 & ND & $4.27 \pm 0.06$ & $6.26 \pm 0.04$ & $4.17 \pm 0.00$ & $6.41 \pm 0.12$ \\
\hline 14 & & & &
\end{tabular}

*ND: not detected.

\subsection{Sensorial Analysis of Beverages}

The results of the 5-level hedonic scale used to evaluate the fermented beverages of pineapple and passion fruit are shown in Figure 4. The pineapple beverage had a mean global rating of $3.3 \pm 0.9$ and the passion fruit drink of $3.9 \pm 0.8$, the latter being the drink with the highest acceptability among tasters. Both drinks had a positive acceptability score of above 3.

For the pineapple beverage, aroma and texture were the attributes most accepted by tasters with scores of $3.9 \pm 0.9$ and $3.8 \pm 0.9$, respectively, followed by flavor with a score of $3.2 \pm 0.9$. On average, tasters rated intensity as $2.7 \pm 0.9$ for acidity and $3.0 \pm 1.0$ for sweetness.

For the passion fruit beverage, the acceptability scores for the texture, flavor and aroma attributes were relatively close, with scores of $3.9 \pm 0.8,3.8 \pm 0.8$ and $3.7 \pm 0.9$, respectively. The tasters estimated the average intensity of $2.7 \pm 1.0$ for acidity and $3.3 \pm 0.8$ for sweetness. 


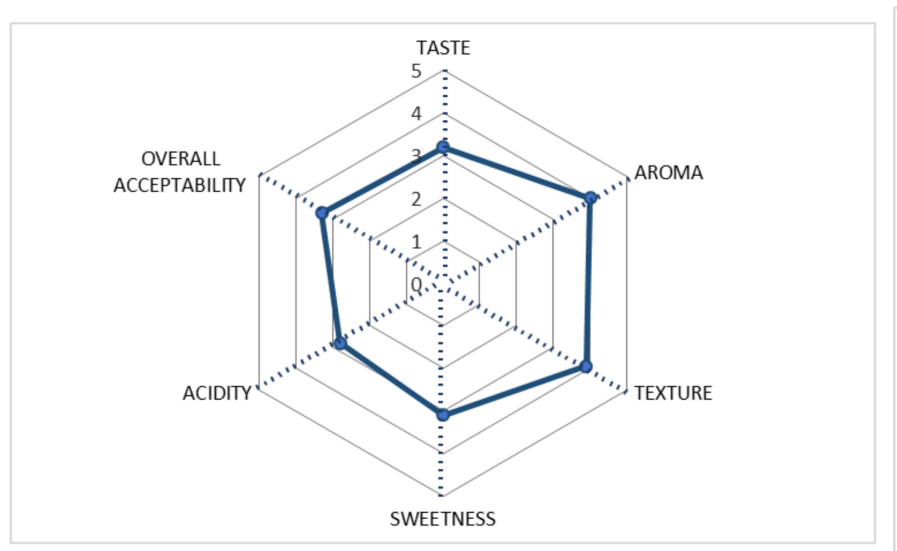

(a)

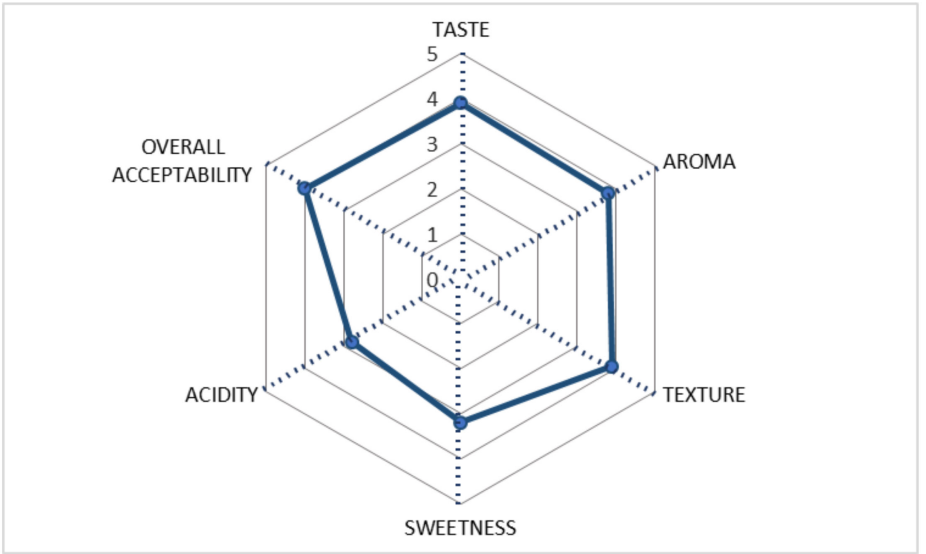

(b)

Figure 4. Sensory evaluation of beverages (scores 1-5) of fermented whey beverages: (a) pineapple beverage; (b) passion fruit beverage.

\section{Discussion}

The results of the screening for bacterial strains with the ability to produce GABA confirm data reported in several studies in which the ability of LAB to produce GABA varied according to species and strain [15,31-34]. In addition, several studies suggest that LAB strains isolated from dairy products may have greater potential for GABA production than strains isolated from non-dairy products [33,35].

Of the 27 LABs studied, E. malodoratus (strains SJC24, SJC25 and SJC26) stands out as having a high potential for GABA production (11-13 $\mathrm{g} / \mathrm{L})$, with conversion rates in the culture medium of approximately $40 \%$. These values are higher than those of several studies that found lower GABA levels (1-6 g/L) in MRS broth enriched with monosodium glutamate (MSG) and under identical fermentation conditions $\left(30{ }^{\circ} \mathrm{C}, 48 \mathrm{~h}\right)$ [36-38]. As far as we know, this is the first study describing this species as a producer of GABA. Most studies investigating GABA-producing LABs have been conducted with the genera Lactobacillus, Lactococcus and Streptococcus, and only a few studies have been conducted with other genera such as Enterococcus [32]. According to some authors, Enterococcus spp. are poor producers of GABA [38-40]. However, Lee et al. [32] reported an E. avium strain that was able to produce high amounts of GABA $(13.9 \mathrm{~g} / \mathrm{L})$. High GABA production was also attributed to strains of L. brevis and L. buchneri isolated from kimchi using MRS broth with 5\% MSG and pH 5.0 and incubated at $37^{\circ} \mathrm{C}$ for $48 \mathrm{~h}$ [41,42]. In the present study, strains of E. malodoratus achieve comparable levels of GABA production in MRS broth and are also considered high GABA producers. However, there are differences related to the fermentation conditions and the composition of the medium, such as the initial amounts of glutamate or MSG, which may be a determining factor for the GABA concentrations obtained.

In both the fermented pineapple and passion fruit beverages, the conversion rates of glutamate to GABA were very high (50-71\%) and higher than the conversion rates obtained in MRS broth culture medium (maximum conversion of $43.5 \%$ for LAB SJC25). This result suggests that whey beverages are more favorable matrices for the production of GABA. A relatively small amount of GLU $(5 \mathrm{~g} / \mathrm{L})$ was initially added to the whey before fermentation to reduce the amount of GLU in the beverage. However, the amount of glutamate remaining in the beverages after fermentation was significantly reduced (to $4-9 \%$ of the initially added amount) and reached negligible levels (20-40 mg/100 mL) in the final product. This is noteworthy because high levels of GLU or MSG added to foods have raised some health questions and their safety has caused concern among both researchers and consumers [43,44]. Moreover, the high GABA levels reached at the end of fermentation (2.6-3.1 g/L) do not decrease when stored at $4{ }^{\circ} \mathrm{C}$ for 14 days, suggesting that the GABA in the beverage is not converted into other metabolites. This GABA content may have beneficial effects on blood pressure control, among other potential effects [13,14]. For 
example, daily intake of $10 \mathrm{mg}$ GABA for 12 weeks was shown to be effective in individuals with mild hypertension [45].

Similar levels to the present work (2.7 g/L GABA) were obtained in skim milk fermented with Lactococcus lactis ssp. lactis isolated from a cheese starter [46]. Other researchers prepared a yogurt with the GABA-producing $S$. thermophilus strain and obtained a similar concentration of GABA (2 mg/mL) in the final product [7]. Similar conversion rates of GLU to GABA were also obtained in beverages prepared with different ingredients, such as brown rice juice, germinated soy juice and skim milk fermented with Lactococcus lactis subsp. lactis [47], boiled black soy milk fermented with L. brevis [14], red seaweed beverage fermented with L. plantarum and 1\% MSG [48], adzuki bean milk fermented with L. rhamnosus [49], lychee juice fermented with L. plantarum [50] and sprouted oat flour fermented with L. plantarum [51].

In the present study, the acidity and $\mathrm{pH}$ values obtained for both beverages are in accordance with the expected acidity values for this type of product [7]. The low $\mathrm{pH}$ of whey resulting from the addition of GLU provides favorable conditions for enhanced production of GABA, as the acidity has been shown to promote the activity of glutamic acid decarboxylase (GAD) [50]. In addition, rapid acidification at the beginning of storage is desirable because low $\mathrm{pH}$ inhibits the growth of pathogenic and spoilage microorganisms. During storage of whey-based beverage, maintenance of low $\mathrm{pH}$ is checked, which is beneficial for the properties of the product. Fluctuations in $\mathrm{pH}$ may contribute to the development of undesirable sensory and structural properties of the product [7].

According to some authors, the rate of milk acidification is an extremely important technological factor in the production of fermented milk [52]. In the present study, the strain of E. malodoratus remained viable during 14 days storage at $4{ }^{\circ} \mathrm{C}$, which could be due to its high acid tolerance (data not show). Viable counts of E. malodoratus SJC25 remained relatively constant (approximately $6 \mathrm{Log} \mathrm{CFU} / \mathrm{mL}$ ) throughout the refrigerated storage. Although there is no general consensus on the recommended levels of probiotics to achieve beneficial effects on host health, it has been suggested that the viability of probiotics should be maintained at $10^{6}-10^{7} \mathrm{CFU} / \mathrm{mL}$ until the expiry date [53]. The number of viable cells of E. malodoratus at the end of the storage period is consistent with this criterion, suggesting that this beverage can be considered a probiotic food. However, since enterococci do not have QPS status [54], the use of E. malodoratus strains as probiotics requires further evaluation of their safety. Previous studies have shown that the strain E. malodoratus SFC25 has neither the presence of virulent genes nor resistance to relevant antibiotics such as vancomycin [27].

The results of the present study showed that the chemical composition of the beverages was comparable to that of whey and whey-based beverages $[18,19,23,25]$. The high moisture values of the whey beverages were expected due to the high percentage of whey used in the formulation of the product and are in line with acceptable values for liquid yogurts (maximum 91.5\% moisture). The average protein content was also similar to whey [55]. Whey proteins have been reported to have a variety of beneficial effects, both nutritionally and on health [21]. In terms of total sugar content, these levels are slightly lower than many liquid yogurts [56]. Both beverages had a fat content comparable to semi-skimmed yogurt, which has a fat content of about $1.4 \%$ [55].

Consumer perception is a critical factor in the development of novel foods, as it influences consumers' willingness to purchase them. In this regard, acidity has a great impact on the quality characteristics of fermented dairy products and is one of the factors limiting their acceptance. Although the fermentation time was prolonged, there were no undesirable changes in the whey beverage. E. malodoratus had no negative effect on the aroma of the beverages, as a mean of 4 was reported for the passion fruit beverage on the five-point hedonic scale. Despite reports attributing to this species the production of $\mathrm{H}_{2} \mathrm{~S}$, which causes an unpleasant odor [57], this characteristic was not observed at all in the beverages produced. 


\section{Conclusions}

As far as we know, this is the first work describing E. malodoratus as a potential producer of GABA, and the high conversion rates obtained should be emphasized. The GABA concentrations obtained in the produced beverages are higher or equivalent to the amounts reported in the literature, which are necessary to have beneficial effects on consumer health, especially in the control of hypertension. From the results of the present study, it can be concluded that a daily intake of $100 \mathrm{~mL}$ of these fermented whey-based beverages would provide a total of 250-300 $\mathrm{mg}$ of GABA.

Whey proved to be a favorable matrix for the production of GABA, which when combined with fruit preparations resulted in a dairy beverage with satisfactory sensory properties (evaluated by the selected panel), suggesting that its integration into the daily eating habits of consumers may be feasible. The beverages developed in this work are an excellent alternative for the use of whey, as it is possible to include in their formulation a large proportion of whey in the liquid phase with good sensory acceptability.

Author Contributions: Conceptualization, D.S.C. and C.C.G.S.; methodology, M.C.C. and C.C.G.S.; investigation, D.S.C., M.C.C. and S.C.R.; writing-original draft preparation, D.S.C.; writing-review and editing, S.C.R. and C.C.G.S. All authors have read and agreed to the published version of the manuscript.

Funding: This work was financially supported by Portuguese Foundation for Science and Technology-FCT, Project UIDB/00153/2016. M.C. Coelho is thankful to Fundação para a Ciência e Tecnologia (FCT) for Ph.D. scholarship SFRH/BD/110227/2015. S.C. Ribeiro is thankful to the Regional Science and Technology Fund (FRCT) for financial support-grant M3.1.a/F/017/2018.

Acknowledgments: The authors are thankful to Institute of Agricultural and Environmental Research and Technology (IITAA), University of the Azores.

Conflicts of Interest: The authors declare no conflict of interest.

\section{References}

1. Kolady, D.; Kattelmann, K.; Vukovich, C.; Scaria, J. Awareness and use of probiotics among the millennials in the United States: Drivers and implications. Funct. Foods Health Dis. 2018, 8, 505-518. [CrossRef]

2. Saxelin, M. Probiotic formulations and applications, the current probiotics market, and changes in the marketplace: A European perspective. Clin. Infect. Dis. 2008, 46, S76-S79. [CrossRef] [PubMed]

3. Jam, S.A.M.; Talebi, M.; Alipour, B.; Khosroushahi, A.Y. The therapeutic effect of potentially probiotic Lactobacillus paracasei on dimethylhydrazine induced colorectal cancer in rats. Food Biosci. 2021, 41, 101097.

4. Han, L.; Sakane, I.; Mizuno, M. Synergistic anti-allergy activity using a combination of Enterococcus faecalis IC-1 and luteolin. Food Biosci. 2021, 41, 100924. [CrossRef]

5. Yerlikaya, O.; Saygili, D.; Akpinar, A. An application of selected enterococci using Bifidobacterium animalis subsp. lactis BB-12 in set-style probiotic yoghurt-like products. Food Biosci. 2021, 41, 101096.

6. Szlufman, C.; Shemesh, M. Role of probiotic bacilli in developing synbiotic food: Challenges and opportunities. Front. Microbiol. 2021, 12, 811. [CrossRef] [PubMed]

7. Linares, D.M.; O'Callaghan, T.F.; O'Connor, P.M.; Ross, R.P.; Stanton, C. Streptococcus thermophilus APC151 strain is suitable for the manufacture of naturally GABA-enriched bioactive yogurt. Front. Microbiol. 2016, 7, 1876. [CrossRef] [PubMed]

8. FAO/WHO. Guidelines for the Evaluation of Probiotics in Food; World Health Organization: London, UK; Food and Agriculture Organization: Guelph, ON, Canada, 2002.

9. $\quad$ Linares, D.M.; Gómez, C.; Renes, E.; Fresno, J.M.; Tornadijo, M.E.; Ross, R.P.; Stanton, C. Lactic acid bacteria and bifidobacteria with potential to design natural biofunctional health-promoting dairy foods. Front. Microbiol. 2017, 8, 846. [CrossRef]

10. Vitellio, P.; Chira, A.; De Angelis, M.; Dumitrascu, D.L.; Portincasa, P. Probiotics in psychosocial stress and anxiety. A systematic review. J. Gastrointest. Liver Dis. 2020, 29, 77-83. [CrossRef]

11. Mindus, C.; Ellis, J.; van Staaveren, N.; Harlander-Matauschek, A. Lactobacillus-based probiotics reduce the adverse effects of stress in rodents: A meta-analysis. Front. Behav. Neurosci. 2021, 15, 642757. [CrossRef]

12. Zhang, N.; Zhang, Y.; Li, M.; Wang, W.; Liu, Z.; Xi, C.; Huang, X.; Liu, J.; Huang, J.; Tian, D. Efficacy of probiotics on stress in healthy volunteers: A systematic review and meta-analysis based on randomized controlled trials. Brain Behav. 2020, 10, e01699. [CrossRef] [PubMed]

13. Diana, M.; Quílez, J.; Rafecas, M. Gamma-aminobutyric acid as a bioactive compound in foods: A review. J. Funct. Foods 2014, 10, 407-420. [CrossRef] 
14. Ko, C.Y.; Lin, H.-T.V.; Tsai, G.J. Gamma-aminobutyric acid production in black soybean milk by Lactobacillus brevis FPA 3709 and the antidepressant effect of the fermented product on a forced swimming rat model. Process Biochem. 2013, 48, 559-568. [CrossRef]

15. Dhakal, R.; Bajpai, V.K.; Baek, K.-H. Production of GABA ( $\gamma$-aminobutyric acid) by microorganisms: A review. Braz. J. Microbiol. 2012, 43, 1230-1241. [CrossRef]

16. Terpou, A.; Papadaki, A.; Lappa, I.K.; Kachrimanidou, V.; Bosnea, L.A.; Kopsahelis, N. Probiotics in food systems: Significance and emerging strategies towards improved viability and delivery of enhanced beneficial value. Nutrients 2019, 11, 1591. [CrossRef]

17. Carvalho, F.; Prazeres, A.R.; Rivas, J. Cheese whey wastewater: Characterization and treatment. Sci. Total Environ. 2013, 445, 385-396. [CrossRef]

18. Skryplonek, K.; Dmytrów, I.; Mituniewicz-Małek, A. Probiotic fermented beverages based on acid whey. J. Dairy Sci. 2019, 102, 7773-7780. [CrossRef]

19. Saglam, H.; Sarioglu, T.; Karahan, A.G.; Oner, Z. An investigation for the development of whey-based probiotic beverages. Rom. Biotechnol. Lett. 2019, 24, 1097-1106. [CrossRef]

20. Tranjan, B.C.; Cruz, A.G.; Walter, E.H.; Faria, J.A.; Bolini, H.M.; Moura, M.R.; Carvalho, L.M. Development of goat cheese whey-flavoured beverages. Int. J. Dairy Technol. 2009, 62, 438-443. [CrossRef]

21. Ryan, M.P.; Walsh, G. The biotechnological potential of whey. Rev. Environ. Sci. Bio/Technol. 2016, 15, 479-498. [CrossRef]

22. Tripathi, V.; Jha, Y. Development of whey beverage with antagonistic characteristics and probiotics. Int. J. Food Prop. 2004, 7, 261-272. [CrossRef]

23. Thakkar, P.; Vaghela, B.; Patel, A.; Modi, H.; Prajapati, J. Formulation and shelf life study of a whey-based functional beverage containing orange juice and probiotic organisms. Int. Food Res. J. 2018, 25, 1675-1681.

24. Schoina, V.; Terpou, A.; Papadaki, A.; Bosnea, L.; Kopsahelis, N.; Kanellaki, M. Enhanced aromatic profile and functionality of cheese whey beverages by incorporation of probiotic cells immobilized on pistacia terebinthus resin. Foods 2020, 9, 13. [CrossRef]

25. Islam, M.Z.; Tabassum, S.; Harun-ur-Rashid, M.; Vegarud, G.E.; Alam, M.S.; Islam, M.A. Development of probiotic beverage using whey and pineapple (Ananas comosus) juice: Sensory and physico-chemical properties and probiotic survivability during in-vitro gastrointestinal digestion. J. Agric. Food Res. 2021, 4, 100144. [CrossRef]

26. Yamahata, N.; Toyotake, Y.; Kunieda, S.; Wakayama, M. Application of multiple sensory evaluations to produce fermented beverages made from sole whey using Kluyveromyces marxianus. Int. J. Food Sci. Technol. 2020, 55, 1698-1704. [CrossRef]

27. Coelho, M.C. Lactic Acid Bacteria in Artisanal S. Jorge PDO Cheese: Biodiversity, Technological and Probiotic Properties. Ph.D. Thesis, The Azores University, Angra do Heroísmo, Portugal, 2022.

28. Li, W.; Wei, M.; Wu, J.; Rui, X.; Dong, M. Novel fermented chickpea milk with enhanced level of $\gamma$-aminobutyric acid and neuroprotective effect on PC12 cells. Peer] 2016, 4, e2292. [CrossRef]

29. AOAC. AOAC Official Methods of Analysis. Association of Official Analytical Chemists, 14th ed.; AOAC: Arlington, VA, USA, 1984; pp. 8-34.

30. DuBois, A.B.; Botelho, S.Y.; Bedell, G.N.; Marshall, R.; Comroe, J.H. A rapid plethysmographic method for measuring thoracic gas volume: A comparison with a nitrogen washout method for measuring functional residual capacity in normal subjects. J. Clin. Investig. 1956, 35, 322-326. [CrossRef]

31. Li, H.; Cao, Y. Lactic acid bacterial cell factories for gamma-aminobutyric acid. Amino Acids 2010, 39, 1107-1116. [CrossRef]

32. Lee, K.W.; Shim, J.M.; Yao, Z.; Kim, J.A.; Kim, H.-J.; Kim, J.H. Characterization of a glutamate decarboxylase (GAD) from Enterococcus avium M5 isolated from Jeotgal, a Korean fermented seafood. J. Microbiol. Biotechnol. 2017, 27, 1216-1222. [CrossRef]

33. Pavli, F.; Gkana, E.; Adebambo, O.; Karatzas, K.-A.; Panagou, E.; Nychas, G.-J.E. In vitro screening of $\gamma$-aminobutyric acid and autoinducer-2 signalling in lactic acid bacteria exhibiting probiotic potential isolated from natural black conservolea olives. Foods 2019, 8, 640. [CrossRef]

34. Santos-Espinosa, A.; Beltrán-Barrientos, L.M.; Reyes-Díaz, R.; Mazorra-Manzano, M.Á.; Hernández-Mendoza, A.; GonzálezAguilar, G.A.; Sáyago-Ayerdi, S.G.; Vallejo-Cordoba, B.; González-Córdova, A.F. Gamma-aminobutyric acid (GABA) production in milk fermented by specific wild lactic acid bacteria strains isolated from artisanal Mexican cheeses. Ann. Microbiol. 2020, 70, 12. [CrossRef]

35. Cui, Y.; Miao, K.; Niyaphorn, S.; Qu, X. Production of gamma-aminobutyric acid from lactic acid bacteria: A systematic review. Int. J. Mol. Sci. 2020, 21, 995. [CrossRef] [PubMed]

36. Park, K.-B.; Oh, S.-H. Production of yogurt with enhanced levels of gamma-aminobutyric acid and valuable nutrients using lactic acid bacteria and germinated soybean extract. Bioresour. Technol. 2007, 98, 1675-1679. [CrossRef] [PubMed]

37. Kook, M.-C.; Cho, S.-C. Production of GABA (gamma amino butyric acid) by lactic acid bacteria. Food Sci. Anim. Resour. 2013, 33, 377-389. [CrossRef]

38. Ribeiro, S.C.; Domingos-Lopes, M.F.; Stanton, C.; Ross, R.P.; Silva, C.C. Production of-aminobutyric acid (GABA) by Lactobacillus otakiensis and other Lactobacillus sp. isolated from traditional Pico cheese. Int. J. Dairy Technol. 2018, 71, 1012-1017. [CrossRef]

39. Franciosi, E.; Carafa, I.; Nardin, T.; Schiavon, S.; Poznanski, E.; Cavazza, A.; Larcher, R.; Tuohy, K.M. Biodiversity and $\gamma-$ aminobutyric acid production by lactic acid bacteria isolated from traditional alpine raw cow's milk cheeses. BioMed Res. Int. 2015, 2015, 625740. [CrossRef]

40. Ly, D.; Mayrhofer, S.; Agung Yogeswara, I.; Nguyen, T.-H.; Domig, K.J. Identification, classification and screening for $\gamma$-aminobutyric acid production in lactic acid bacteria from cambodian fermented foods. Biomolecules 2019, 9, 768. [CrossRef] 
41. Shin, J.-W.; Kim, D.-G.; Lee, Y.-W.; Lee, H.-S.; Shin, K.-S.; Choi, C.-S.; Kwon, G.-S. Isolation and characterization of Lactobacillus brevis AML15 producing $\gamma$-aminobutyric acid. J. Life Sci. 2007, 17, 970-975. [CrossRef]

42. Cho, S.Y.; Park, M.J.; Kim, K.M.; Ryu, J.-H.; Park, H.J. Production of high $\gamma$-aminobutyric acid (GABA) sour kimchi using lactic acid bacteria isolated from mukeunjee kimchi. Food Sci. Biotechnol. 2011, 20, 403-408. [CrossRef]

43. Thuy, L.N.; Salanta, L.; Tofana, M.; Socaci, S.A.; Fărcaș, A.C.; Pop, C. A mini review about monosodium glutamate. Bull. UASVM Food Sci. Technol. 2020, 77, 1-12. [CrossRef]

44. Zanfirescu, A.; Ungurianu, A.; Tsatsakis, A.M.; Nițulescu, G.M.; Kouretas, D.; Veskoukis, A.; Tsoukalas, D.; Engin, A.B.; Aschner M.; Margină, D. A review of the alleged health hazards of monosodium glutamate. Compr. Rev. Food Sci. Food Saf. 2019, 18, 1111-1134. [CrossRef]

45. Inoue, K.; Shirai, T.; Ochiai, H.; Kasao, M.; Hayakawa, K.; Kimura, M.; Sansawa, H. Blood-pressure-lowering effect of a novel fermented milk containing $\gamma$-aminobutyric acid (GABA) in mild hypertensives. Eur. J. Clin. Nutr. 2003, 57, 490-495. [CrossRef]

46. Nomura, M.; Kimoto, H.; Someya, Y.; Furukawa, S.; Suzuki, I. Production of $\gamma$-aminobutyric acid by cheese starters during cheese ripening. J. Dairy Sci. 1998, 81, 1486-1491. [CrossRef]

47. Lu, X.; Xie, C.; Gu, Z. Optimisation of fermentative parameters for GABA enrichment by Lactococcus lactis. Czech J. Food Sci. 2009, 27, 433-442. [CrossRef]

48. Ratanaburee, A.; Kantachote, D.; Charernjiratrakul, W.; Penjamras, P.; Chaiyasut, C. Enhancement of $\gamma$-aminobutyric acid in a fermented red seaweed beverage by starter culture Lactobacillus plantarum DW12. Electron. J. Biotechnol. 2011, 14, 1-14.

49. Song, H.Y.; Yu, R.C. Optimization of culture conditions for gamma-aminobutyric acid production in fermented adzuki bean milk. J. Food Drug Anal. 2018, 26, 74-81. [CrossRef]

50. Wang, D.; Wang, Y.; Lan, H.; Wang, K.; Zhao, L.; Hu, Z. Enhanced production of $\gamma$-aminobutyric acid in litchi juice fermented by Lactobacillus plantarum HU-C2W. Food Biosci. 2021, 42, 101155. [CrossRef]

51. Aparicio-García, N.; Martínez-Villaluenga, C.; Frias, J.; Peñas, E. Production and Characterization of a Novel Gluten-Free Fermented Beverage Based on Sprouted Oat Flour. Foods 2021, 10, 139. [CrossRef]

52. Han, M.; Liao, W.-y.; Wu, S.-m.; Gong, X.; Bai, C. Use of Streptococcus thermophilus for the in situ production of $\gamma$-aminobutyric acid-enriched fermented milk. J. Dairy Sci. 2020, 103, 98-105. [CrossRef]

53. Kempka, A.P.; Krüger, R.L.; Valduga, E.; Di Luccio, M.; Treichel, H.; Cansian, R.; Oliveira, D.d. Formulation of a peach-flavored dairy drink using alternative substrates and probiotic culture. Food Sci. Technol. 2008, 28, 170-177. [CrossRef]

54. Koutsoumanis, K.; Allende, A.; Alvarez-Ordóñez, A.; Bolton, D.; Bover-Cid, S.; Chemaly, M.; Davies, R.; De Cesare, A.; Hilbert, F Scientific Opinion on the update of the list of QPS-recommended biological agents intentionally added to food or feed as notified to EFSA (2017-2019). EFSA J. 2020, 18, e05966. [PubMed]

55. Henriques, M.H.; Gomes, D.M.; Pereira, C.J.; Gil, M.H. Effects of liquid whey protein concentrate on functional and sensorial properties of set yogurts and fresh cheese. Food Bioprocess Technol. 2013, 6, 952-963. [CrossRef]

56. Kang, S.-S.; Kim, M.K.; Kim, Y.-J. Comprehensive evaluation of microbiological and physicochemical properties of commercial drinking yogurts in Korea. Food Sci. Anim. Resour. 2019, 39, 820. [CrossRef] [PubMed]

57. Collins, M.; Jones, D.; Farrow, J.; Kilpper-Balz, R.; Schleifer, K. Enterococcus avium nom. rev., comb. nov.; E. casseliflavus nom. rev., comb. nov.; E. durans nom. rev., comb. nov.; E. gallinarum comb. nov.; and E. malodoratus sp. nov. Int. J. Syst. Evol. Microbiol. 1984, 34, 220-223. [CrossRef] 